Trans. R. ent. Soc. Lond. 127 (I), pp. 33-50, 4 figs. 1975

\title{
A comparison, by sweep sampling, of the arthropod fauna of secondary vegetation in Michigan, England and Costa Rica
}

\author{
DANIEL H. JANZEN AND CAROLINE M. POND \\ Department of Zoology, University of Michigan, Ann Arbor, Michigan, U.S.A. \\ Department of Zoology, Oxford, England
}

\begin{abstract}
SUMMARY
I. Six 800-sweep samples of English and Michigan ("old field") secondary vegetation arthropods are compared with Costa Rican samples taken in the same way.

2. Parasitic Hymenoptera and spiders accounted for a larger proportion of the arthropod fauna in the mid-latitude than the tropical samples.

3. In one English field, the seasonal change in insect numbers was $88 \%$ of that recorded over all the seasonal and elevational changes examined in Costa Rica. Furthermore, the difference in the total dry weights of the arthropod fauna between December and July was similar to the difference found between the wet and dry seasons in tropical secondary vegetation (also similar to the difference between day and night values during the dry season).

4. Aphids and Psyllidae were far more abundant in the English site than in the Costa Rican mainland sites.

5. In mid-summer, the English field had far more arthropods in it than did any of the tropical sites sampled.
\end{abstract}

An overall appreciation of the structure of the arthropod fauna collected with a standardised sweep net in tropical vegetation is developing (Allan et al., r973; Janzen, r973a,b; Janzen et al., I975; Janzen \& Schoener, r968; Schoener \& Janzen, I968). Hitherto there have been no directly comparable samples from mid-latitude vegetation. This study describes sweep net samples of a Michigan "old field" and English "old fields", and speculates upon the ecological significance of the more conspicuous differences between them and Costa Rican sweep samples of secondary vegetation ("old fields" in midlatitude terminology).

\section{METHODS}

The sweep samples were taken in the manner described by Janzen (r973a,b), with the same qualifications and levels of resolution being applicable. In brief, eight subsamples of Ioo sweeps each were taken by one of us (C.M.P.) using a $40 \mathrm{~cm}$ ( ${ }_{5} \mathrm{in}$ ) diameter muslin sweep net. The insects in each subsample were killed with ethyl acetate, separated immediately from the vegetation and put (dry) into Petri dishes. Most orders were sorted to species and these were counted while keeping the eight subsamples separate; only after counting were the data pooled to single 800-sweep samples. All determinations to 
morphospecies were made by D.H.J., and there is no reason to suspect differential taxonomic discrimination from sample to sample, or between the temperate and the tropical ones. Oven-dry weights were determined within a few months of collection.

The sample sites, described below, were chosen to provide a direct comparison with various "old field" and secondary vegetation habitats in Costa Rica (described by Janzen, r $973 a, b)$. Sweeps were taken in the late morning when possible, and always in sunny weather with the upper foliage dry. Though rarely contacted with the sweep net, sometimes there was dew on shaded lower foliage. In the Bridford 1973 site, the 800-sweep sample was taken from almost exactly the same piece of vegetation on each date, but within an 800-sweep sample the vegetation was only swept once.

SAMPLE AREAS

\section{Michigan 1972}

This site (fig. IA) is the highway right-of-way on the north side of Michigan State Road C64 (road to Pellston), $4.3 \mathrm{~km}$ west of the entrance to the Douglas Lake Biological Station, Douglas Lake, Michigan ( $44^{\circ} 57^{\prime}$ latitude). Pellston, a few kilometres west of the site, receives an average of $794 \mathrm{~mm}$ precipitation per year and August averages $72 \mathrm{~mm}$. It has an annual daily average maximum temperature of $1 \mathrm{I} \cdot 3^{\circ} \mathrm{C}$ and minimum of $-0.9^{\circ} \mathrm{C}$; the May, July, August, September and December monthly average maxima/ minima temperatures are respectively $17.5 / 3.0,25 \cdot 9 / 11 \cdot 0,24.9 / 10 \cdot 6,19 \cdot 8 / 6.7$ and $9.6 /$ $-\mathrm{I} \cdot 2^{\circ} \mathrm{C}$. The site was swept on 3 rd August, 1972 between 8.30 and 9. Io hours, when fully insolated under a clear sky with scudding clouds and with an air temperature of $19^{\circ} \mathrm{C}$. The vegetation contacted by the net included foliage of mature grasses, herbaceous perennial dicots, and young shrubs and trees. The area swept was about $300 \times 50 \mathrm{~m}$, bounded on the north by mixed hardwood and conifer forest and on the south by the ditch bordering the asphalt highway. The sweep site vegetation continues to the east and west of the site for many kilometres, and is the consequence of thorough clearing five to ten years ago. There was no sign of fire having occurred within the past three to five years, and there was no livestock on the site, though deer (Odocoileus) have access. The site had not been mowed for three to five years. In addition to at least five species of grasses, the plants listed in Appendix I were common and made up at least $50 \%$ of the volume of vegetation contacted by the sweep net.

\section{Bridford 1972}

This site (fig. $\mathrm{xB}$ ) is a lightly used $\mathrm{r} 2$-ha horse pasture on a north-west-facing slope approximately $1.5 \mathrm{~km}$ south-east of Bridford, Devonshire, England ( $50^{\circ} 45^{\prime}$ latitude). Kennick, a few kilometres from Bridford, receives an average of I I $57 \mathrm{~mm}$ precipitation per year and August averages $98 \mathrm{~mm}$ (average of I96r to I969). It has an annual daily average maximum temperature of $13.9^{\circ} \mathrm{C}$ and minimum of $6.6^{\circ} \mathrm{C}$; the May, July, August, September and December monthly average maxima/minima temperatures are respectively $16 \cdot 0 / 7 \cdot 1,20 \cdot 6 / 1 \mathrm{I} \cdot 9,20 \cdot 4 / 1 \mathrm{I} \cdot 6,18.4 / 10.2$ and $8.4 / 3.3^{\circ} \mathrm{C}$. The site was swept on I 9 th August, 1972 between 9.25 and 10.00 hours, when fully insolated under a clear sky with the air temperature at $14^{\circ} \mathrm{C}$. The vegetation contacted by the net was foliage of mature grasses and herbaceous perennials, and ranged from 40 to $120 \mathrm{~cm}$ tall. The area swept was about $70 \times 130 \mathrm{~m}$. The field is bounded by a dense 10-1 $5 \mathrm{~m}$ tall closed-canopy woodland of Quercus robur L., Corylus avellana L., Tilia cordata Mill., Ilex aquifolium L. 


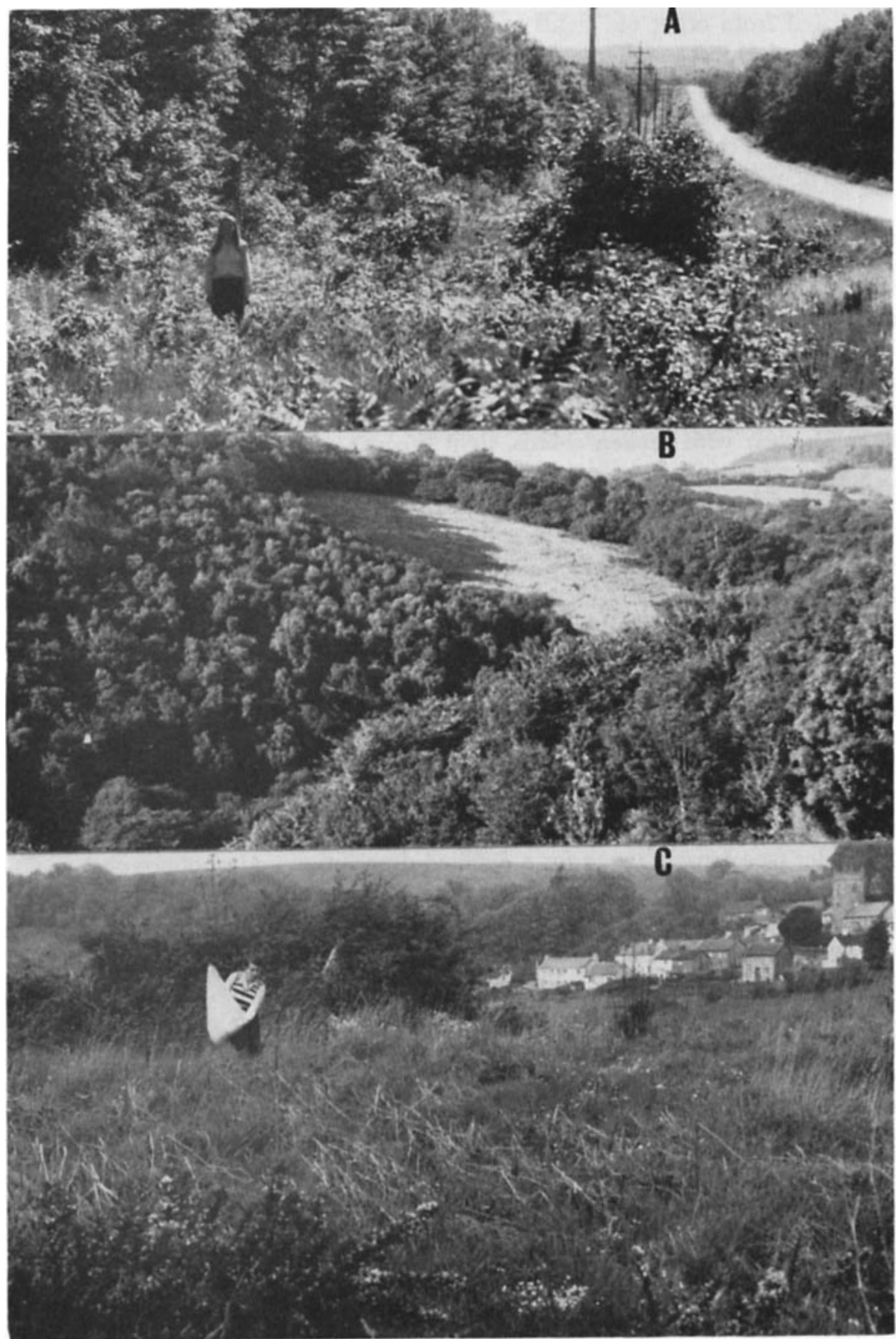

Fig. I. Sample sites. (A) Centre of Michigan 1972 sweep site. (B) The insular pasture among the woods is the Bridford I $_{972}$ sweep site. (C) Centre of Bridford 1973 sweep site (village in background is Bridford). 
Sorbus aucuparia L., Acer pseudoplatanus L., Salix cinerea L., and Fraxinus exelsior L. While isolated from other old fields and pastures, the vegetation was similar in species composition and aspect to other young regenerating sites in the vicinity. Horses had worn scattered trails through the vegetation but had not flattened it. In other years this site was sometimes heavily grazed by cattle. The herbaceous plants listed in Appendix II made up at least $95 \%$ of the vegetation contacted by the net (grasses constituted about $25 \%$ of the volume of vegetation contacted).

\section{Bridford 1973}

This site (fig. IC) is a $\mathbf{2 \cdot 4}$-ha patch of waste land (including old rockpiles) on the crest of a hill centred in a $4^{\circ} 0$-ha wheat field about $0.5 \mathrm{~km}$ east of Bridford. The wheat field is bounded by dense hedges. In 1973, the site was swept on 26th May (10.00-I 1.00 hours, $19^{\circ} \mathrm{C}$, clear with scudding clouds, light breeze), 28 th July (I4.30-1 5.30 hours, $21^{\circ} \mathrm{C}$, hazy sunshine with broken clouds, very dry with no wind), 3oth September (10.15-1 1.30 hours, $15^{\circ} \mathrm{C}$, clear with broken clouds, light breeze), and $25^{\text {th }}$ December (12.30-13.10 hours, $5^{\circ} \mathrm{C}$, clear with light breeze, frost on foliage at ground level). The wheat field was never burned and was cut on 28th August (it was $25 \mathrm{~cm}$ tall in late May and the stubble was ploughed under in October). The site is never grazed but was lightly burned in $197 \mathrm{I}$ or earlier. The sweep area contained the species of plants listed in Appendix III. Flowers were present in the vegetation during May, July and September samples; the proportion of grass contacted by the sweep net was greatest in September. In December, most of the vegetation contacted was dead. In all four samples, the vegetation was 30 to $100 \mathrm{~cm}$ tall.

\section{Costa Rica}

Five Costa Rican sample sites are frequently mentioned in this study. We follow the site

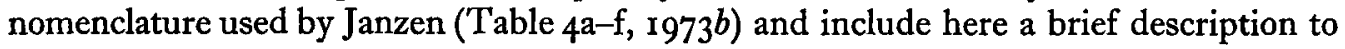
aid the reader (see Janzen $1973 a$ for a detailed description and photographs).

Osa secondary. Ungrazed regenerating vegetation on old gravel pits bounded on one side by a river and on the other side by primary (undisturbed evergreen rainforest, sea level). Samples were taken in the wet and dry season; during the dry season (February and March) there is less rain, many more hours of clear skies, and diel temperature fluctuations greater than in the rainy season.

Taboga abandoned pasture. Ungrazed regeneration in an old pasture cut out of a narrow strip of semi-deciduous to evergreen riparian forest passing through deciduous forest (sea level). Samples were taken in the wet and dry season. This site is not as dry as a pasture cut from deciduous forest (e.g. Taboga pasture, Fig. 4, Janzen r973a) but is much drier than the nearby riparian forest.

San Vito corn field. Lightly grazed regeneration in an abandoned corn field that been cut out of montane evergreen rainforest ( $1250 \mathrm{~m}$ elevation).

Cerro $1740 \mathrm{~m}$. Very lightly grazed regeneration in an abandoned corn field that had been cut out of evergreen old secondary successional forest (I $740 \mathrm{~m}$ elevation).

Cerro $3340 \mathrm{~m}$. Lightly grazed woody regeneration following infrequent burning of evergreen forest for pasture and charcoal production ( $3340 \mathrm{~m}$ elevation). The extraordinarily slow rate of vegetation regeneration at this site has been described by Janzen (1973c). 


\section{Number of species}

\section{RESULTS AND DISCUSSION}

At the Bridford 1973 site, there was a seven-fold change in the number of species from mid-winter to mid-summer, with the number of species of adult insects in the sample

Table r. Species (sp) and individuals (ind) taken in samples of 800 sweeps in the Bridford old field, I973, Bridford 1972 and Michigan 1972 sites (mites and Thysanoptera were not enumerated owing to their small size)

\begin{tabular}{|c|c|c|c|c|c|c|c|c|c|c|c|c|}
\hline & \multicolumn{8}{|c|}{ Bridford I 973} & \multirow{2}{*}{\multicolumn{2}{|c|}{$\begin{array}{l}\text { Bridford } \\
\text { I } 972 \\
\text { I9 Aug. }\end{array}$}} & \multirow{2}{*}{\multicolumn{2}{|c|}{$\begin{array}{l}\text { Michigan } \\
\text { I } 972 \\
3 \text { Aug. }\end{array}$}} \\
\hline & \multicolumn{2}{|c|}{26 May } & \multicolumn{2}{|c|}{28 July } & \multicolumn{2}{|c|}{30 Sept. } & \multicolumn{2}{|c|}{25 Dec. } & & & & \\
\hline & sp. & ind. & sp. & ind. & sp. & ind. & & ind. & sp. & ind. & sp. & ind. \\
\hline \multicolumn{13}{|l|}{ Adult } \\
\hline Coleoptera & 80 & IIOI & 80 & 853 & 55 & $6 \mathrm{Ir}$ & 33 & 197 & 39 & 357 & 29 & 198 \\
\hline Hemiptera-Heteroptera & 12 & $23 I$ & 20 & 1392 & I I & I6I & 5 & $3^{8}$ & 20 & 560 & 24 & 278 \\
\hline Homoptera* & 9 & 121 & I 8 & 1473 & 16 & 502 & IO & 185 & Ig & Iorg & 42 & 725 \\
\hline Diptera & 67 & I 459 & I 20 & $244 \mathrm{I}$ & 43 & 687 & I7 & 218 & 98 & 1226 & 104 & 639 \\
\hline \multicolumn{13}{|l|}{ Hymenoptera } \\
\hline Formicidae & 3 & $2 I_{I}$ & 4 & 66 & $\mathbf{I}$ & $\mathbf{I}$ & $\circ$ & $\circ$ & I & $\mathbf{I}$ & I I & 1216 \\
\hline $\begin{array}{l}\text { Bees and wasps and } \\
\text { sawflies }\end{array}$ & 7 & 13 & 8 & 25 & 0 & $\circ$ & 0 & $\circ$ & 6 & $3 I$ & r 5 & 42 \\
\hline Para. Hymenop. & 84 & 248 & 225 & 2401 & 57 & 105 & 5 & 6 & I 28 & 418 & 72 & 216 \\
\hline Orthoptera & 0 & o & 2 & 8 & I & 8 & 0 & $\circ$ & $\circ$ & $\circ$ & 5 & 12 \\
\hline Lepidoptera & 4 & 334 & ro & 103 & 0 & 0 & 0 & 0 & 8 & 12 & I5 & 33 \\
\hline Neuroptera & I & I & o & o & 0 & o & o & 0 & I & I & 0 & 0 \\
\hline Trichoptera & o & o & o & o & $\circ$ & $\circ$ & o & 0 & I & I & $\circ$ & $\circ$ \\
\hline Mecoptera & $\mathbf{I}$ & & o & o & o & o & 0 & 0 & I & 2 & I & 5 \\
\hline Total & 268 & 3720 & 487 & 8762 & 184 & 2075 & & 644 & 322 & 3628 & 318 & 3364 \\
\hline \multicolumn{13}{|l|}{ Immature } \\
\hline Hemiptera-Heteroptera & & 29 & & 8509 & & 54 & & 0 & & Iro5 & & 203 \\
\hline Homoptera* & & 27 & & 22 & & 6 & & $2 \mathrm{x}$ & & 36 & & II 9 \\
\hline Aphids & & 387 & & 1380 & & 59 & & 2 & & 1328 & & 259 \\
\hline Orthoptera & & 4 & & 158 & & 4 & & $\circ$ & & 7 & & 18 \\
\hline Lepidoptera $†$ & & 77 & & 354 & & I94 & & 25 & & 47 & & 85 \\
\hline Dermapteraf & & II & & 5 & & 23 & & 0 & & $\circ$ & & o \\
\hline Neuroptera & & o & & 2 & & 0 & & $\circ$ & & $\circ$ & & 3 \\
\hline Total & & 535 & & $10,43^{\circ}$ & & 340 & & 48 & & 2523 & & 687 \\
\hline \multicolumn{13}{|l|}{ Other } \\
\hline Spiders§ & & 397 & & 952 & & 322 & & 270 & & 657 & & IIO \\
\hline Isopods & & 8 & & 9 & & 6 & & 3 & & $\circ$ & & 0 \\
\hline Millipedes & & I & & 0 & & $\mathbf{I}$ & & 0 & & 0 & & 0 \\
\hline Total & & 406 & & $96 \mathrm{I}$ & & 329 & & 273 & & 657 & & rio \\
\hline Grand total & & $466 \mathrm{I}$ & & 20,153 & & 2744 & & 965 & & 6808 & & $4 \mathrm{r} 6 \mathrm{I}$ \\
\hline $\begin{array}{l}\% \text { of the insects that } \\
\text { were immature }\end{array}$ & & $\mathbf{r}_{3}$ & & 54 & & $\mathrm{r}_{4}$ & & 7 & & $4 I$ & & 17 \\
\hline
\end{tabular}

* Not including aphids.

† Including beetle larvae, which constitute less than $I \%$ of the individuals.

$\ddagger$ Includes adults and nymphs.

$\S$ Includes harvestmen. 


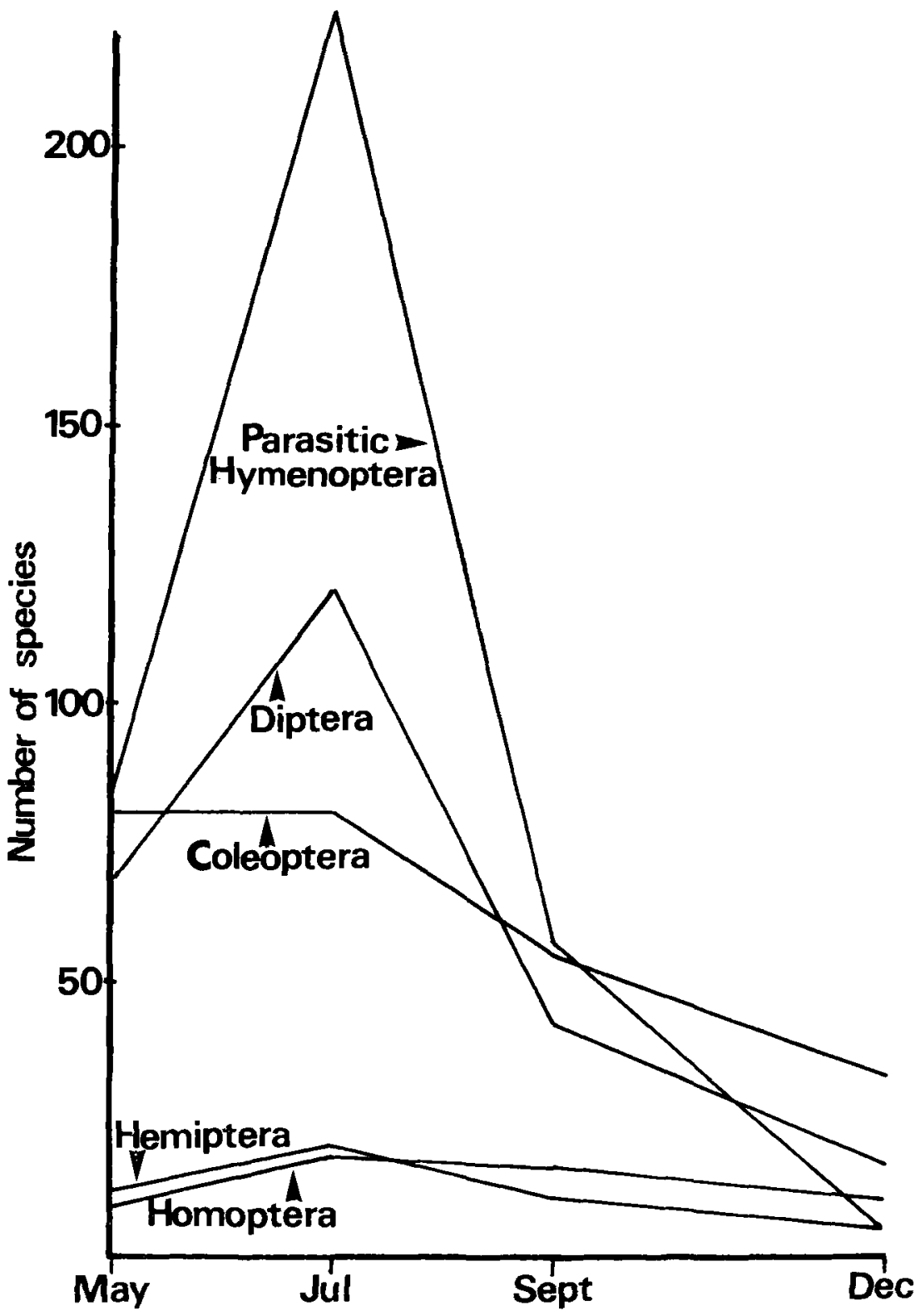

Fig. 2. Species sweep curves for the Bridford I 973 sweep site.

increasing from 268 species in May to a peak of 487 species in July, followed by a gradual decline to 184 species in September and 70 species in December (Table 1 ). The Bridford 1972 sample (taken in August about halfway between the Bridford 1973 July and September samples) had the expected intermediate number of 322 species of adult insects. The Michigan 1972 sample ( 318 species) is amazingly close in overall species richness. The only other temperate zone sample available for comparison, i.e. Baldwin Woods secondary ('Table I, Janzen I973a; Table $4 \mathrm{j}$, Janzen $1973 b$ ), had 142 species of 
adult insects, which seems consistent with the English and Michigan samples, since it was taken in late September.

The orderly seasonal changes in the richness of the adult insect fauna documented in Table I are by no means the result of proportional changes in each insect order. Figure 2 shows that parasitic Hymenoptera undergo a 45 -fold change in species richness from July to December, whereas Coleoptera show only a $2 \cdot 7$-fold change during the same period; species richness in adult Hemiptera (i.e. Heteroptera) and Homoptera is equally stable whereas Diptera change seven-fold.

Unlike the other orders, the Coleoptera do not increase in species richness in the middle of the summer. This could be a result of sample error. To examine this possibility, we plotted species-sweep curves for the adult beetles alone (fig. $3 \mathrm{~A}$ ). The September and December curves level-off before 800 sweeps are reached, and the beetle-species richness for these samples is probably the maximum detectable with this sampling technique. Both the May and July samples appear as though they would level-off at about go species, showing that maximum beetle-species richness is attained well before the mid-summer peak in overall insect species richness. The same possibility of sample error examined for the adult Hemiptera (fig. $3^{B}$ ) showed further sweeps would not have changed appreciably the values graphed in figure 2.

Adult Coleoptera, Hemiptera, and Homoptera species were collated between the Bridford 1973 July, September and December samples. $51 \cdot 3 \%$ of the Coleoptera species present in July reappeared in the September sample, and $4 \mathrm{I} \cdot 3 \%$ were still present on Christmas Day. The corresponding figures for adult Hemiptera are $35 \%$ and $25 \%$, and for adult Homoptera, $47.9 \%$ and $44 \%$. Conversely, $81.8 \%$ of the Coleoptera in thi September sample were present in the July sample and all the Coleoptera species in the mid-winter sample had been present in July. The corresponding figures for adult Hemiptera are $63.6 \%$ and $100 \%$, and for the adult Homoptera, $87.5 \%$ and $80 \%$ (failure to achieve $100 \%$ in this last figure was due to the appearance of two new species of Psyllidae in the sample). It is impossible to know if these seasonal changes in fauna represent local migrations or in situ population changes, but the large changes in numbers of individuals recorded for all groups (fig. 4), suggest that the latter were very important.

The three orders discussed in the previous paragraph are primarily phytophagous, and they made an interesting contrast with carnivorous groups. There was a 45 -fold change in the numbers of parasitic Hymenoptera species, but a subjective impression of the spiders was that most species were present in all four samples. These results are expected from the very different biologies of the two taxa; parasitic Hymenoptera usually overwinter as immature stages in their host or nearby, whereas many English spiders overwinter as potentially active adults up in the vegetation. Two species of predaceous Hemiptera (adult Anthocoridae and Reduviidae) and four species of ladybirds (Coccinellidae) were present in all four samples. Few Staphylinidae and Carabidae were present because of the inappropriate method of sampling for these groups.

There are six 800-sweep samples from Costa Rican secondary vegetation available (Table $4^{a-f}$, Janzen 1973 ) for comparison with the five complete samples described here. The most important comparisons are:

(I) There are far more species of parasitic Hymenoptera in the July Bridford 1973 sample (225 species) than in any of the Costa Rican secondary vegetation samples. This vegetation is derived from lowland rainforest (wet season, 33 species; dry season, 104 species) and intermediate elevation rainforest (dry season, I08 species) as well as sites 
expected to be less rich in parasitic Hymenoptera. This difference between mid-latitude and tropical sweep samples is even more striking in view of the fact that the tropical site sampled was only a few metres from intact forest. The only tropical sweep samples that have produced parasitic Hymenoptera with a species richness approaching that of the July Bridford 1973 sample are the intermediate elevation forest understory samples (San Vito primary I, 376 species; San Vito primary II, 294 species), and these sites had about twice as many total insect species ( 969 and 767 ) as the July Bridford 1973 sample $(487$ species). In short, the parasitic Hymenoptera of secondary vegetation do not increase in

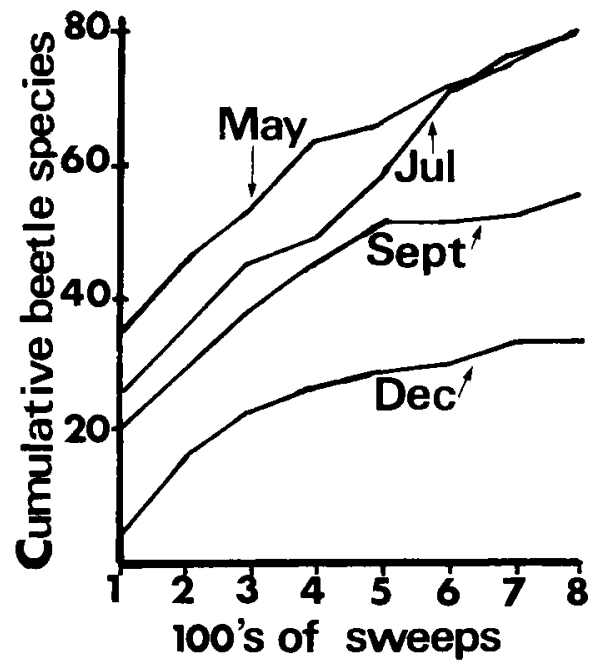

A

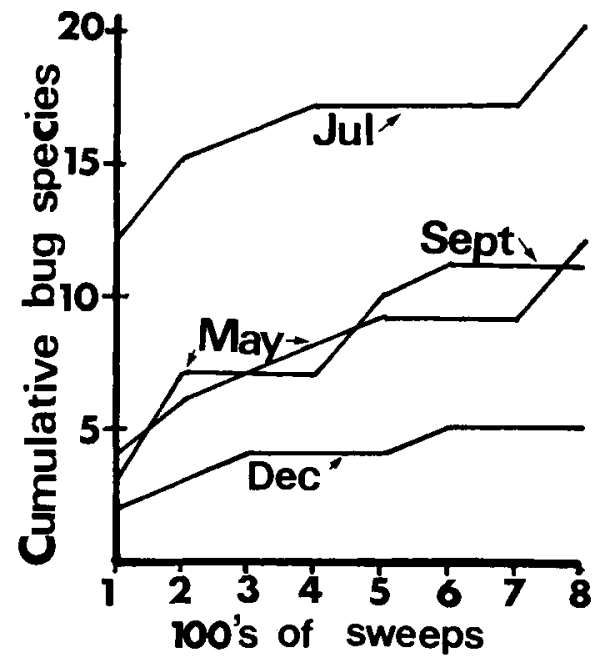

B

Fig. 3. Changes in numbers of selected groups of species with season at the Bridford 1973 sweep site.

species richness from the mid-latitude to the lowland tropical samples nearly as much as in other orders. Owen \& Owen (1974) have also found this true of English and African garden ichneumonids. Studies on particular groups of prey insects (Bruchidae and Lepidoptera larvae, see Janzen, $1973^{d}$ ) in Costa Rica suggest that this is a general phenomenon, not one restricted to early stages of succession. Furthermore, comparison of the Cerro $3340 \mathrm{~m}$ sample (Table $4 \mathrm{f}$, Janzen, $1973^{b}, 4^{8}$ species of parasitic Hymenoptera out of 178 species in total) with the other lowland tropical samples, shows that the more rigorous high elevation conditions do not limit the species richness of parasitic Hymenoptera as severely as they do other groups such as Coleoptera, Hemiptera, and ants. We offer the following preliminary explanation for the comparatively low, within-habitat species richness of parasitic Hymenoptera in species-rich tropical insect communities. The biomass of the large number of tropical prey species is divided into many dissimilar species, each one often being too rare to sustain a species of parasites. The biomass of mid-latitude insects consists of fewer species in larger populations, each large enough to support numerous species of parasitic Hymenoptera. Between-habitat species richness has not been considered here, but this may also be low in the tropics as compared with the mid-latitudes. Taxonomists have long noted that parasitic Hymenoptera faunas seem 
much larger for mid-latitude areas, but have attributed this to ineffective collecting in the tropics. The sweep sample data presented here suggests that it is a real ecological phenomenon.

(2) Although no species enumerations are available, the data in Table I show that aphids contribute a much greater proportion to the mid-latitude than to the tropical sweep samples. In 35 Costa Rican samples of 800 sweeps, Janzen (1973 b) saw only three individual aphids (San Vito corn field). The bright yellow and presumably distasteful aphid Aphis nerii, found in mainland secondary vegetation (on Ascelepias curassavica) was the only aphid observed in Costa Rica (outside of crop lands) that was not tended by ants, and even aphids tended by ants were rare. There were at least five to ten species of aphids in each of the Michigan and English samples. At least two processes may be responsible for this pattern which contrasts with that observed for insects as a whole. (i) Aphids are colonising species whose populations grow asexually throughout much of the summer; they depend on an initially fast-growing and chemically poorly protected food source and low predator-parasite densities in spring, in order to survive with no sexual reproduction during the first half of the summer. In a tropical habitat, where populations of parasites and predators fluctuate less, where plants are better protected chemically and where their growing season is spread more evenly through the year, the aphid's developmental strategy is probably a very poor one. (ii) With very few exceptions (such as Aphis nerii mentioned above), aphids are about the most poorly protected of all insects in the community. They escape by not being found, which is an unsuccessful mechanism in low to intermediate elevation tropical habitats, where virtually every leaf may be searched by a predator (birds, ants, Hemiptera, parasitic Hymenoptera) every day of the year. Their absence from high tropical mountains is probably associated with the very slow and uniform growth rates of plants growing there (Janzen, 1973c). By contrast, they are a prominent part of the insect fauna on Caribbean islands (Janzen, $1973 \mathrm{~b}$ ). Island habitats have fewer predators and the vegetation may be less well protected chemically, owing to low herbivore loads.

(3) No Michigan, English or Kansas (Baldwin Woods, Table $4 \mathrm{j}$, Janzen, $1973 b$ ) sample had more than five species of adult Orthoptera (including cockroaches, mantids, stick insects, grasshoppers, crickets and katydids). This is a much greater decrease in species numbers than found when comparing all insects in lowland tropical and midlatitude samples. Large insects such as Orthoptera (and especially hemimetabolous orders) should have more difficulty in completing a generation in the short northern summer than smaller insects (Schoener \& Janzen, 1968). Many tropical orthopterans have life spans that exceed the length of a temperate zone growing season.

(4) In the English samples; the ratios of adult beetle species to adult Homoptera species are generally greater than in the Costa Rican samples. A similar difference is equally striking when the beetles are compared with adult Hemiptera in the Bridford I973 samples. In each of these samples, about $21 \%$ of the beetle species and $5 \%$ of the Hemiptera species were carnivores as adults. There are two possible explanations: (i) When overall plant species-richness increases, proportionately more sucking than chewing insects can be "stacked" into the ecosystem. (ii) As the growing season becomes shorter, and plant growth more concentrated within a shorter period, the sucking insects (dependent in great part on the rate of flow of nutrients from one part to another of the plant) are affected more than the chewing insects. The latter hypothesis is supported by the observation that in tropical vegetation, as we move from secondary vegetation into 
adjacent forest understory, the Hemiptera/Homoptera species richness is suppressed far more than is the species richness of Coleoptera (Janzen, I973b).

(5) The range of species richness of adult insects throughout the year at the Bridford I 973 site $(487$ to 70 , difference 417 ) was similar to the overall range among all of the Costa Rican secondary vegetation sites $(639$ to 178 , difference $46 \mathrm{r})$ notwithstanding the fact that the Costa Rican sites range from secondary vegetation in lowland evergreen rainforest to highly seasonal forest to evergreen forest at $3340 \mathrm{~m}$ elevation. The Bridford I 973 difference is only 1.22 times as great as that found between the wet and dry season in secondary vegetation in lowland evergreen forest (difference 342 , Janzen, 1973 $b$, compare Tables $4^{a}$ and $4 b$ ). Comparison of the number of adult Coleoptera and Hemiptera species ( 78 and 18 ) taken in the wet season in a pasture at a very seasonal site (Taboga abandoned pasture, Table I, Janzen, $1973 b$ ) with the total species increase at this site during the wet season shows that the wet season-dry season change in total insect species was 425 (650 minus 225 , see Table 4 c, Janzen, I $\left.973^{b}\right)$ i.e. about the same as that experienced in a full year's cycle in southern England. In short, we have recorded within one English field a seasonal change in insect numbers in the vegetation that is $88 \%$ of that recorded over all the seasonal and elevational changes in Costa Rica.

(6) At the Bridford sites, there are noticeably fewer species of ants (o to 4) than at the three lowland tropical sites (Io to 25 , Table $4^{\mathrm{a}-c}$, Janzen, $1973^{b}$ ), substantiating our subjective impression of the low numbers of species (and individuals) of ants on temperate zone foliage as compared with tropical lowland foliage. However, at $\mathrm{I} 500$ to $2200 \mathrm{~m}$ in the tropics the numbers of ant species are similar to those in England, and above about $2500 \mathrm{~m}$ ant species are absent (Janzen, 1973b). Ants may be less abundant in the two Bridford sweep sites because: (i) an ant colony is a large organism (with a long generation time), requiring a large amount of food per year. The more the food supply is confined to one part of the year (see fig. 4 and Table 2), the fewer the species that can be maintained. (ii) The Bridford sites are comparatively cool and damp, and ground level vegetation is moist through most of the summer months. These factors may be a major reason for the absence of ants at elevations exceeding about $2500 \mathrm{~m}$ on moist tropical mountains (Janzen, I 973 $b$ ); likewise, the Bridford sites are comparatively poor physical environments for ants, which are bound to the substrate for warmth. In short, it is not a cold winter but a cool summer that is inimical to ants in Bridford. This hypothesis gains some support from the observation that there are more species (I I species, Michigan, I972; 6 species, Baldwin Woods secondary, Table $4 \mathrm{j}$, Janzen, $1973 b$ ) in the other temperate zone sites, which are drier and hotter in the summer but much colder in the winter.

\section{Species diversity}

Without attempting to determine the dubious biological significance of species diversity indices such as $\mathrm{H}^{\prime}$ (and see criticisms in De Benedictis, 1973), it is worth comparing the seasonal changes in $\mathrm{H}^{\prime}$ and how they change with latitude. In general, $\mathrm{H}^{\prime}$ increases as the number of species per individual in the sample increases and/or as the distribution of individuals among the species in the sample becomes more uniform; both of these circumstances generally represent an increase in what is subjectively called 'diversity'. Tropical values are available only for adult Coleoptera and Hemiptera (Janzen, 1973b), so only those are discussed here. 


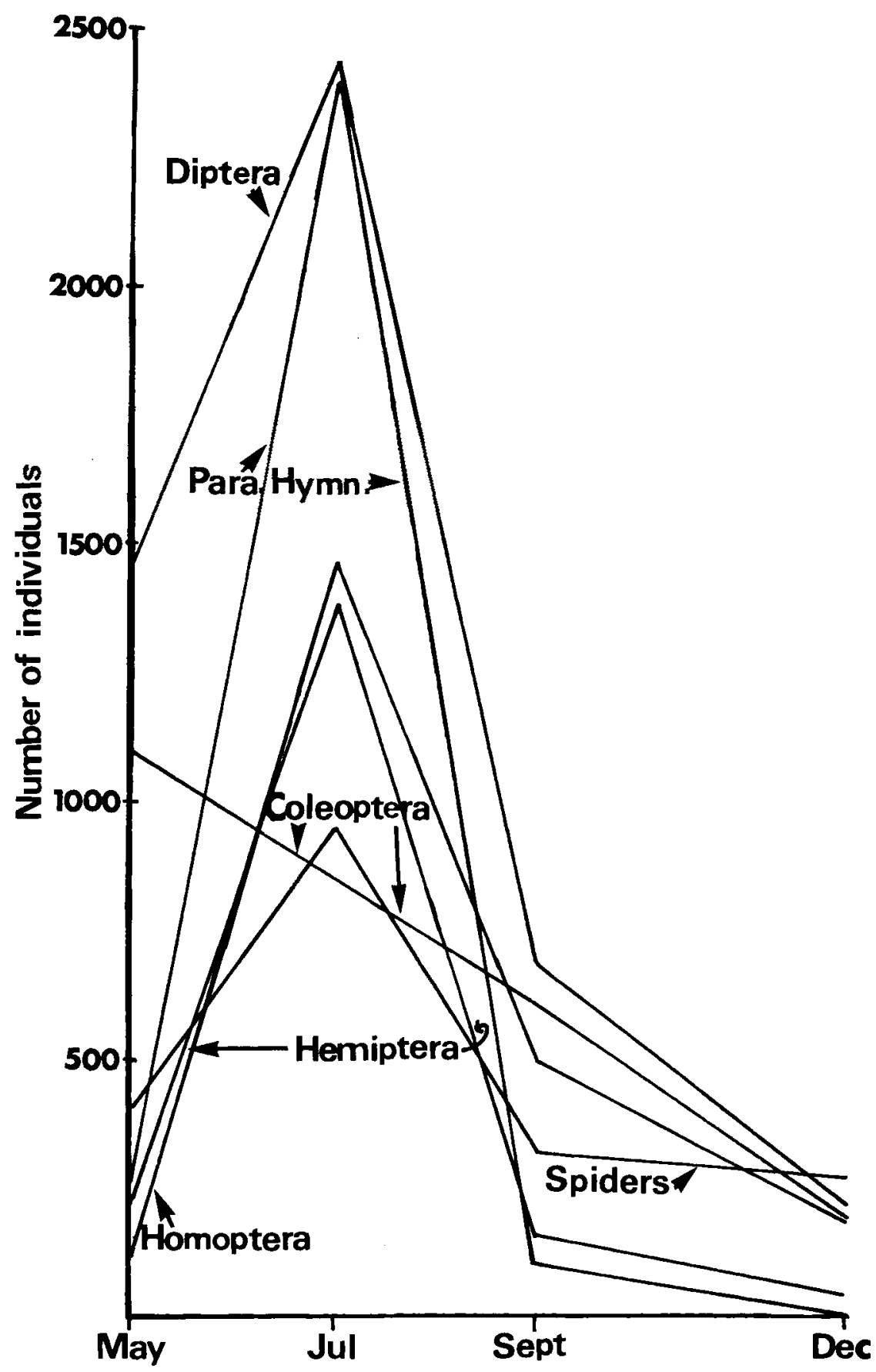

Fig. 4. Changes in numbers of adult individuals with season at the Bridford 1973 sweep site. 
Table 2. The percentage dry weight of the separate categories of the arthropod fauna in each sample (80o sweeps) from the Bridford I973, Bridford 1972 and Michigan 1972 sample sites

\begin{tabular}{|c|c|c|c|c|c|c|}
\hline \multirow[b]{2}{*}{ Category } & \multicolumn{4}{|c|}{ Bridford I 973} & \multirow{2}{*}{$\begin{array}{l}\text { Bridford } \\
\text { I } 972 \\
\text { I9 Aug. }\end{array}$} & \multirow{2}{*}{$\begin{array}{l}\text { Michigan } \\
1972 \\
3 \text { Aug. }\end{array}$} \\
\hline & 26 May & 28 July & 30 Sept. & 25 Dec. & & \\
\hline \multicolumn{7}{|l|}{ Adult } \\
\hline Coleoptera & $25 \cdot 8$ & $10 \cdot I$ & I $8 \cdot 4$ & $14 \cdot 6$ & $6 \cdot 6$ & $15 \cdot 2$ \\
\hline Hemiptera-Heteroptera & $13 \cdot 4$ & $9 \cdot 1$ & $7 \cdot 8$ & $10 \cdot 1$ & $3 \cdot 2$ & $4 \cdot 3$ \\
\hline Homoptera* & $1 \cdot 9$ & $14 \cdot 6$ & $14 \cdot 8$ & $2 I \cdot 0$ & $22 \cdot 9$ & $\mathrm{I} 2 \cdot 8$ \\
\hline Diptera & $13 \cdot 6$ & 10.8 & IO. I & $10 \cdot 9$ & $33 \cdot 3$ & $9 \cdot 3$ \\
\hline \multicolumn{7}{|l|}{ Hymenoptera } \\
\hline Formicidae & $2 \cdot 4$ & 0.2 & 0.02 & - & 0.007 & $10 \cdot 8$ \\
\hline Bees and wasps & $\mathrm{I} \cdot 5$ & $2 \cdot 8$ & - & - & $5 \cdot 3$ & $6 \cdot 2$ \\
\hline Para. Hymenoptera & $I \cdot 5$ & $\mathbf{I} \cdot 7$ & 0.9 & $0 \cdot 10$ & 0.7 & 0.8 \\
\hline Orthoptera & 一 & $I \cdot 3$ & $5 \cdot 5$ & - & $I \cdot I$ & $4 \cdot 4$ \\
\hline Lepidoptera & $x \cdot 3$ & $2 \cdot 6$ & - & $\longrightarrow$ & 0.7 & 0.7 \\
\hline Neuroptera & 0.2 & 0.01 & - & 一 & 0.006 & 一 \\
\hline Trichoptera & - & - & - & 一 & $0 \cdot 1$ & - \\
\hline Mecoptera & 0.09 & 一 & - & 一 & 0.2 & 0.4 \\
\hline \multicolumn{7}{|l|}{ Immature } \\
\hline Hemiptera-Heteroptera & 0.05 & $22 \cdot 1$ & 0.6 & 一 & $5 \cdot 2$ & $4 \cdot 0$ \\
\hline Homoptera* & 0.3 & $0 . \mathrm{r}$ & 0.02 & 0.6 & $2 \cdot I$ & 0.7 \\
\hline Aphids & $1 \cdot 3$ & $\mathrm{I} \cdot 8$ & 0.2 & 0.02 & $\mathrm{I} \cdot 6$ & 0.5 \\
\hline Orthoptera & - & $8 \cdot \mathbf{r}$ & 0.5 & - & - & $19 \cdot 9$ \\
\hline Lepidoptera $†$ & $18 \cdot 3$ & $3 \cdot 6$ & $20 \cdot 8$ & $14 \cdot 7$ & $2 \cdot 0$ & $7 \cdot 6$ \\
\hline Dermapteraf & $2 \cdot 5$ & 0.4 & $6 \cdot I$ & - & 0.7 & - \\
\hline Neuroptera & 一 & 0.01 & 一 & 一 & 一 & 一 \\
\hline \multicolumn{7}{|l|}{ Other } \\
\hline Spiders & I5 I & $10 \cdot 5$ & $\mathrm{I} 4 \cdot \mathrm{I}$ & $27 \cdot 8$ & $14 \cdot 2$ & $2 \cdot 6$ \\
\hline Isopods & 0.6 & 0.1 & 0.1 & 0.4 & - & - \\
\hline Millipedes & 0.4 & - & 0.2 & 一 & - & - \\
\hline Total weight $(\mathrm{g})$ & $5 \cdot 86$ & $22 \cdot 49$ & $8 \cdot 07$ & 0.96 & $16 \cdot 51$ & $10 \cdot 06$ \\
\hline
\end{tabular}

Footnotes. For explanation see Table I.

In the Bridford 1973 samples, the $\mathrm{H}^{\prime}$ values (base 2 ) were $3.3 \mathrm{r}, 2 \cdot 88,2.88$ and 2.50 for beetles in May, July, September and December respectively. $\mathrm{H}^{\prime}$ for beetles in the Bridford 1972 (August) and Michigan 1972 (August) samples were 2.67 and 2.82 respectively. The Bridford $\mathbf{I} 972$ and Michigan 1972 values are very similar to those from the comparable times in the Bridford 1973 samples. The comparable Hemiptera $\mathrm{H}^{\prime}$ values were $0 \cdot 67, I \cdot 37, I^{\circ} 45$ and $I \cdot I I$ for Bridford 1973 . The Bridford 1972 and Michigan I972 Hemiptera $H^{\prime}$ values were $\mathrm{r} \cdot 80$ and $2 \cdot 28$.

There are only five instances in the $35 \mathrm{H}^{\prime}$ values reported for mainland Costa Rican beetle samples ('Table I, Janzen, I973b) where the $\mathrm{H}^{\prime}$ values are as low as those reported here for mid-latitude samples. Three samples from the same cattle pasture during the dry season (Taboga pasture) had $\mathrm{H}^{\prime}$ values of $2 \cdot 79,2.67$ and $2 \cdot 13$; however, they had only I I to I 6 species of beetles as compared with the 29 to 80 species in the mid-latitude samples. The San Vito corn field had $\mathrm{H}^{\prime}$ values of 2.47 (63 species of beetles) and is thus most similar to the mid-latitude samples; however, only a few metres away in the primary 
forest were the highest $\mathrm{H}^{\prime}$ and species richness of beetles of any sweep sample ever taken $\left(\mathrm{H}^{\prime}=7 \cdot 4^{\mathrm{I}}\right.$ and $3 \mathrm{I} 2$ species). Finally, the Cerro $334^{\circ} \mathrm{m}$ sample (a wet tropical mountaintop) had an $\mathrm{H}^{\prime}$ of 2.90 for 27 species of beetles. Summarising, there were three instances where the $\mathrm{H}^{\prime}$ values of a tropical beetle community were similar to those of a mid-latitude beetle community: in secondary vegetation in rainforest, at $3340 \mathrm{~m}$ elevation, and during a severe six-month dry season.

The adult tropical Hemiptera samples have much higher $\mathrm{H}^{\prime}$ values than the Bridford 1973 samples in all instances except two. One of the rainforest understory samples (Osa primary-flat, dry season, Table I, Janzen, $\mathrm{I} 973^{b}$ ) had an $\mathrm{H}^{\prime}$ value of $\mathrm{I} \cdot 37$, but it had only three species and five individuals. One of the Taboga pasture samples, taken in the dry season, had an $\mathrm{H}^{\prime}$ of $\mathrm{I} \cdot 00$ but it had only two species and two individuals. The $\mathrm{H}^{\prime}$ values for the Michigan 1972 and Bridford 1972 samples are slightly higher than that for the Bridford 1973 sample but are still very low compared with the tropical samples.

\section{Numbers of individuals}

At the Bridford 1973 site, there was a $2 \mathrm{I}$-fold change in arthropod numbers between the July and December samples (Table I). We are aware that these seasonal changes in insects taken with a sweep net do not necessarily reflect the overall density of arthropods in the entire region (inter-microhabitat migration obviously contributing much to the seasonal change), but they are obviously important to the plants and to the predators within a habitat.

Each arthropod group did not display seasonal change proportional to the $2 \mathrm{I}$-fold change in total arthropods (fig. 4). Just as with the number of species, the number of individuals of parasitic Hymenoptera had the largest seasonal change (400-fold) and the spiders the least $(3 \cdot 5$-fold). Neither the number of species nor the number of individuals of the Coleoptera followed the seasonal fluctuations of the overall array of insects. Probably the number of adult beetles declines as the year progresses because most species have only one generation per year, and overwinter as last instar larvae or pupae that have matured from eggs laid in the previous spring.

The mid-summer rise in density (fig. 4) is expected of insect groups that may have several generations during the year, or require only part of the growing season to reach maturity. This pattern is reflected in the enormous increase in immature insects in the July sample $(54 \%$ of the individuals, Table 1 ). However, the numbers of immature insects in the different orders did not fluctuate in the same way. Homopteran nymphs were as abundant on Christmas Day as in July, whereas hemipteran nymphs showed a 8509 -fold difference between these two dates. Part of the answer to this dramatic difference lies in the fact that just over $95 \%$ of the hemipteran nymphs belonged to two closely related species of Miridae whereas Philaenus spumarius (Cercopidae), the most common homopteran at the site at mid-summer, has nymphs that were too low in the vegetation to be caught by the sweep net.

The range in arthropod numbers found in the Bridford 1973 samples ( 965 to $20, I_{53}$, difference 19,188 ) is considerably greater than that found in the six very different Costa Rican samples $\left(5^{\circ} 74^{8}\right.$ to $59 \mathrm{I}$, difference $5 \mathrm{I} 57$; Table $4 \mathrm{a}-\mathrm{f}$, Janzen, I973 $b$; unfortunately there is a transposition error in column two to Table $4 \mathrm{a}$ and the number 1907 should read 1097). However, despite this much smaller range in the tropical sites, in the dry season the highly seasonal Taboga abandoned pasture (Table $4 c$, Janzen, $1973^{b}$ ) had substantially fewer individuals than the Bridford 1973 site in mid-winter. When the 
numbers of Coleoptera were extrapolated to estimate the overall arthropod density during the rainy season in this deciduous forest site, the value of 4196 individual arthropods was obtained ( 783 beetles from Table I divided by I I 0 beetles from Table $4 \mathrm{c}$ and multiplied by $59 \mathrm{I}$ individuals from Table $4 \mathrm{c}$, all from Janzen, $1973 \mathrm{~b}$ ). This suggests that none of these lowland tropical sites had anything like the seasonal variation in numbers of individuals displayed by the Bridford 1973 site; the secondary vegetation near evergreen rainforest varies from 3372 (wet season) to 5748 (dry season) and the secondary vegetation near deciduous forest varies from $59 \mathrm{I}$ to $4 \mathrm{I} 96$ individuals.

During July and August at the Bridford and Michigan sites, arthropods were as abundant or more so than at any season at the tropical secondary vegetation sites (Table $4^{a-f}$, Janzen, $1973^{b}$ ). Not even the heavily shaded understory of riparian evergreen forest during a severe dry season (Column 4 , Table $4 c$, Janzen, $1973^{b}$ ) has as many arthropods as Bridford in May, July and August, and Michigan in August; this riparian evergreen forest is a major haven for adult insects passing the dry season.

In the tropical samples, the percentage of immatures among all insects is remarkably constant for the six secondary vegetation samples (range, 10- $14 \%$, Table $4 \mathrm{a}-\mathrm{f}$, Janzen, $1973 b$ ). In the growing season temperate zone samples it is $13,14,17,41$ and $54 \%$ (including the Baldwin Woods secondary sample, Table $4 \mathrm{j}$, Janzen, 1973 ). This tropical mid-latitude difference reflects the more even distribution of food items through the tropical year. However, the rainy season 'Taboga abandoned pasture sample (only beetles and bugs recorded, Table I, Janzen, $1973 b$ ) had a very high proportion of immature Lepidoptera, Orthoptera and Hemiptera, the result of a habitat that has a large flush of new growth early in the rainy season.

The most striking difference in numbers of adult insects between the tropical and mid-latitude sites was among the parasitic Hymenoptera. In May, July and September 1973, and August 1972 at the Bridford sites, in August 1972 in Michigan, and September at Baldwin Woods secondary, there were 248,2401 , 105, 418,216 and 48 individual parasitic Hymenoptera respectively. In the sample of $240 \mathrm{r}$ parasitic Hymenoptera, the five most abundant species were Entedon distinius Walker (106 individuals), Mesopolobus nobilis (Walker) (139), Tetrastichus conon (Walker) (816), Litomastix truncatellus (Dalman) (121), and Tetrastichus pansisis (Walker) (226). The six tropical secondary vegetation sites had 236, 46, 37, 148, $\mathrm{r} 3 \mathrm{I}$ and 70 individuals (Table 4a-f, Janzen, 1973b). We have earlier discussed why the numbers of species of parasitic Hymenoptera within a habitat may be greater in the mid-latitudes, and the same arguments apply to the numbers of individuals. The one habitat where we might expect a large number of parasitic Hymenoptera in the tropics is secondary vegetation cut from lowland deciduous forest, a month or two after the rainy season begins (a site such as Taboga abandoned pasture, Table $4 \mathrm{c}$, Janzen, $1973 \mathrm{~b}$ ). However, studies in progress on the rates of parasitisation of the insects in such a site strongly suggest that such a parasite "bloom" does not occur. We suggest the following cause. In those tropical habitats that are so seasonal that there are few prey species each with a high population density during the rainy season, the shortage of prey in the dry season usually precludes survival of parasites. As explained earlier, as the habitat becomes less seasonal, the more host species each with fewer individuals causes a decline in the number of parasitic species and individuals.

In contrast to the parasitic Hymenoptera, spiders are generalised predators and different conclusions emerge when their numbers in tropical and mid-latitude sites are compared. In the tropical secondary vegetation samples, spiders constitute 2.3 to $5.6 \%$ 
(average, $3.7 \%$ ) of the total arthropods in all but the dry season sample in secondary vegetation of deciduous forest, where they constitute $12 \%$ of the individuals. This high value in the dry season suggests that they simply survive the dry season in situ rather than migrate or lie dormant. The mid-latitude samples have $2 \cdot 6$ to $11 \cdot 7 \%$ spiders (average $7 \cdot 2 \%$ including Baldwin Woods secondary, Table $4 \mathrm{j}$, Janzen, $1973 b$ ) except for the mid-winter Bridford 1973 sample, which contained $30 \%$ spiders. This suggests that many temperate zone spiders likewise simply pass the inimical season as active individuals. There are two reasons why a greater proportion of the mid-latitude than the tropical samples is made up of spiders: (i) the tropical spider's prey is more diverse in behaviour, morphology, individual defences, etc., so it should have more difficulty obtaining food than its temperate counterpart. (ii) Individual defences are conspicuously lacking among the great majority of the insects in the mid-latitude samples, at least as compared with the tropical samples.

Quantitative data were not recorded, but we had the distinct impression that the array of insects in a tropical sweep sample possess more intense individual defences than do those in mid-latitude samples. The tropical samples contain far more potential mimics and models (usually based on chemical distastefulness) than do the mid-latitude samples. In the Bridford samples, only four beetles species (bloody nose beetle, Timarcha tenebricosa (Fabr.); Propylea 14-punctata (L.); seven-spot ladybird, Coccinella 7-punctata L.; soldier beetle, Rhagonycha fulva (Scop.), and one moth larva, Callimorpha jacobaeae (L.), had aposematic coloration. In the Michigan 1972 sample, only the milkweed beetle (Tetraopes sp.), dogbane beetle (Chrysochus sp.) and the sumac beetle (Calligrapha sp.) had aposematic coloration. These surmised differences in overall palatability of the samples should affect the size of carnivore populations that can be maintained per gram of arthropod in the habitat.

In addition to the extraordinary abundance of aphids in the mid-latitude samples (Table I, and p. 39), the Psyllidae were also unexpectedly numerous. Lowland tropical samples of 800 sweeps characteristically contain one to three species of Psyllidae and one to ten individuals. The Bridford I 973 July sample contained three species and 576 adult individuals. In September there were two species and 78 adults. Even in December there were four species and 39 individuals. Probably, the reason for their abundance in the mid-latitude samples and scarcity in tropical sample is the same as that suggested earlier for aphids.

Although 'Thysanoptera were not counted in the mid-latitude samples, there were hundreds of them in each sample, which is far more than ever encountered in tropical

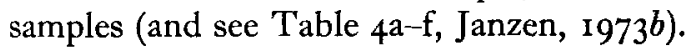

\section{Dry weight}

The dry weight of arthropods increased dramatically during the middle of the summer at the Bridford 1973 site, with a 23 -fold difference between the July and December samples (Table 2). The Bridford 1972 and Michigan 1972 samples had dry weights concordant with the seasonal change at the Bridford 1973 site. For adult insects, the results (Table 2) require only two observations. The disproportionately large amount of beetle dry weight in the September Bridford 1973 sample was due to five individuals of

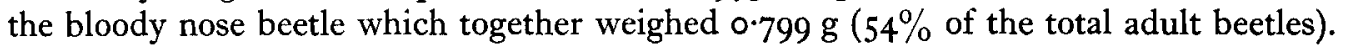
Incidentally, these distasteful beetles are probably unacceptable as food for most predators. The large percentage of adult Diptera in the Bridford 1972 sample was due to 
large numbers of newly emerged Scopeuma lutarium Fab. Among the immatures, only the Lepidoptera deserve special comment; their contribution to total dry weight was noticeably lower in the mid-summer peak of individuals than at other times in the year. Likewise, spiders make up the lowest proportion of the sample dry weight during the time when their potential prey appears to be most abundant.

Comparison of Table 2 with the dry weights for "Total" arthropods in Costa Rican samples (Table 3, Janzen, $1973 b$ ) shows that the highest Bridford value $(22.49 \mathrm{~g})$ is not substantially greater than that of the rainforest site (Osa secondary site at night in the dry season) with $17.96 \mathrm{~g}$. Furthermore, it is the same as deciduous forest pasture ('Taboga abandoned pasture) during the day in the wet season $(2 \mathrm{r} \cdot 6 \mathrm{rg})$ and during the night in the dry season $(22.42 \mathrm{~g})$. However, all three tropical samples mentioned above contained at least 30 to $40 \%$ of their weight in Orthoptera, a group that is very poorly represented in the Bridford July sample. Furthermore, two of these three high tropical values were obtained at night, when densities of large phytophagous insects are considerably increased in the vegetation swept by the net. Although nocturnal sweeps were not taken in the mid-latitude sites, visual inspection did not suggest a similar increase in large insects at night.

Of the lowland tropical secondary vegetation samples, the values range from $2.92 \mathrm{~g}$ (Taboga abandoned pasture, day, dry season, Table 3 , Janzen, 1973b) to the $22.42 \mathrm{~g}$ in the same pasture at night (Taboga abandoned pasture, night, dry season, Table 3, Janzen, $1973 b$ ); this difference of $19.50 \mathrm{~g}$ is not substantially different from the $21.53 \mathrm{~g}$ difference between the July and December Bridford 1973 samples. The difference of $19.5 \mathrm{~g}$ is probably enough to encourage a strong local migration of insectivorous tropical birds, just as the winter-summer changes in mid-latitude insect abundance permit longdistance bird migration. The numbers in the rainforest site (Osa secondary, dry season, Table 3 , Janzen, $1973 b$ ) do not fluctuate nearly so strongly from night to day ( $\mathrm{I} \cdot \mathrm{I} 6 \mathrm{~g}$ in the day, $\mathrm{I} 7.96 \mathrm{~g}$ at night), nor do they fluctuate as strongly from dry season (day, $\mathrm{I} \cdot 16 \mathrm{~g}$ ) to wet season (day, $8.34 \mathrm{~g}$ ) as in the tropical deciduous forest site.

This study was supported by NSF grant GB-35032X and by facilities in the Hope Department of Entomology and the Department of Zoology, Oxford University, England. F.Hartman identified the plants from the Michigan 1972 sample site and S.J.Woodell those from the English sample sites. M.W.R.de V.Graham provided parasitic Hymenoptera determinations. Field facilities were kindly provided by D.A. and M.H.Pond and by the late N.Bassett. P.Becker provided constructive criticism of the manuscript. J. Stout and B.W.Williamson gave aid in constructing computer programs.

\section{APPENDIX I}

\section{Plant species found on Michigan 1972 sample site}

Aster laevis L., Erigeron strigosus Muhl., Achillea millefolium L., Centaurea maculosa Lam., Hieracium aurantiacum L., Solidago canadensis L., Chrysanthemum leucanthemum L., Lactuca canadensis L., Tragopogon major Jacq. (Compositae); Apocynum androsaemifolium L. (Apocynaceae); Acer saccharum Marsh. (Aceraceae); Hypericum perforatum L. (Hypericaceae); Populus tremuloides Michx. (Salicaceae); Amelanchier sanguinea (Pursh) D.C., Rubus sp. (Rosaceae); Meliotus alba Desr., Vicia villosa Roth (Leguminosae); Anemone canadensis L. (Ranunculaceae); Epilobium angustifolium L. (Onagraceae); 
Satureja vulgaris L. (Labiatae); Rhus typhina L. (Anacardiaceae); Pteridium aquilinum (L.) Kuhn (Polypodiaceae); Hesperus matronalis L. (Cruciferae); Verbascum thapsus L. (Scrophulariaceae); and Asclepias syriaca L. (Asclepiadaceae).

\section{APPENDIX II}

Plant species found on Bridford 1972 sample site

Achillea millefolium L., Cirsium vulgare (Savi) Ten., Senecio jacobaea L., Cirsium palustre (L.) Scop., Crepis capillaris (L.) Wallr., Hypochaeris radicata L., Cirsium arvense (L.) Scop. (Compositae); Lotus corniculatus L., Trifolium repens L., Trifolium pratense L. (Leguminosae); Rubus fruticosus agg. (Rosaceae); Prunella vulgaris L. (Labiateae); Urtica dioica L. (Urticaceae); Ranunculus repens L. (Ranunculaceae); Rumex acetosa L. (Polygonaceae); Plantago lanceolata L. (Plantaginaceae); Pteridium aquilinum (L.) Kuhn (Polypodiaceae); Cynosurus cristatus L., Holcus lanatus L., Arrhenatherum elatius (L.) J. and C. Presl., and Agrostis sp. (Gramineae).

\section{APPENDIX III}

\section{Plant species found on Bridford I973 sample site}

Centaurea nigra L., Senecio jacobaea, Cirsium arvense, Taraxacum sp. (Compositae); Heracleum sphondylium L., Chaerophyllum temulum L. (Umbelliferae); Sambucus nigra L. (Caprifoliaceae); Plantago lanceolata, Myosoton aquaticum (L.) Moench, Stellaria graminea L., Stellaria holostea L. (Caryophyllaceae); Vicia sepium L., Vicia cracca L., Vicia sativa L., Cytisus scoparius (L.) Link, Trifolium repens, Trifolium pratense, Lotus corniculatus, Ulex europaeus L. (Leguminosae); Rumex obtusifolius, Rumex acetosa L., Rumex crispus L. (Polygonaceae); Ranunculus sceleratus L., Ranunculus repens L. (Ranunculaceae); Rubus fruticosus agg. (Rosaceae); Galium mollugo (Rubiaceae); Veronica chamaedrys L., Verbascum sp. (Scrophulariaceae); Agrostis stolonifera L., Anthoxanthum odoratum L., Agrostis gigantea Roth., Tragopogon pratensis L., Arrhenathenum elatius, Holcus lanatus, Dactylis glomerata L. (Gramineae); Urtica dioica, Crepis capillaris, Knautia arvensis (L.) Coult.(Dipsacaceae); Pteridium aquilinum (Polypodiaceae); and Endymion nonscriptus (L.) Garcke (Liliaceae).

\section{REFERENCES}

Allan J.D., Barnthouse L.W., Prestbye R.A. \& Strong D.R. 1973. On foliage arthropod communities of Puerto Rican second growth vegetation. Ecology $54: 628-32$.

De Benedictus P.A. 1973. On the correlation between certain diversity indices. Am. Nat. 107 : 295-302.

JANZEN D.H. 1973a. Sweep samples of tropical foliage insects: description of study sites, with data on species abundances and size distributions. Ecology $54: 659-86$.

JANZEN D.H. 1973b. Sweep samples of tropical foliage insects: effects of seasons, vegetation types, elevation, time of day, and insularity. Ibid. $54: 687-708$.

JANZEN D.H. 1973c. Rate of regeneration after a tropical high elevation fire. Biotropica 5 : I I 7-22.

JANZEN D.H. I973d. Comments on host-specificity of tropical herbivores and its relevance to species richness. In V.H.Heywood (ed.) Taxonomy and ecology, Systematics Association Special Volume No. 5, Academic Press, London. Pp. 20I-I I.

Janzen D.H., Ataroff M., Farinas M., Reyes S., Rincon N., Soler A., Soriano P. \& Vera M. 1975. Changes in the arthropod community along an elevational transect in the Venezuelan Andes. Ecology (in press). 
JANZEN D.H. \& Schoener T.W. I968. Differences in insect abundance and diversity between wetter and drier sites during a tropical dry season. Ecology $49: 69-1$ ro.

OWEN D.F. \& OWEN J. I974. Species diversity in temperate and tropical Ichneumonidae. Nature Lond. $249: 583-4$.

SChOENER T.W. \& JANZEN D.H. I 968 . Notes on environmental determinants of tropical versus temperate insect size patterns. Am. Nat. 102 : 207-24.

Manuscript received $\mathrm{I} 7$ th July, 1974 